\title{
GRAIN YIELD AND QUALITY OF SOME EGYPTIAN VARIETIES AS INFLUENCED POWDERY MILDEW INFECTION Hasan, M.A. ${ }^{1}$ and Abeer Elhalwagi ${ }^{2}$ \\ ${ }^{1}$ Plant Pathology Research Institute, Agricultural Research Center, Giza, Egypt \\ ${ }^{2}$ National Gene Bank, Agricultural Research Center, Giza, Egypt
}

\begin{abstract}
Wheat powdery mildew caused by Blumeria graminis f. sp. tritici has recently assumed significance affecting wheat production under Egyptian conditions. Relationship between yield reduction and grain quality and the disease were studied during 2012/13 and 2013/14 growing seasons at Gemmeiza Agricultural Research Station on 9 wheat varieties i.e. Sakha 93, Giza 168, Gemmeiza 7, Gemmeiza 9, Gemmeiza 10, Gemmeiza 11, Misr 1, Misr 2 and Sids 12. Disease severity was 4.33 $\%$ to $41.66 \%$ in $2012 / 13,8.33 \%$ to $51.66 \%$ in $2013 / 14$. Area under disease progress curve (AUDPC) was found to be correlated with powdery mildew severity during the two growing seasons. The highest loss in 1000 kernel weight was recorded on Sakha 93. On the other hand, Sids 12 showed the lowest loss during 2012/13 (1.13\%), whereas Misr 2 showed the lowest loss in 2013/14 season (1.2\%). Regarding the effect of the disease on grain quality, the highest increase in protein content was observed on Sakha 93( $14.14 \%-15.85 \%)$, whereas Giza 168 showed the least increase in protein content .The most affected wheat cultivar in carbohydrate content was found in Gemmeiza 7 (6.64\%). Increase \% in wet gluten content varied from season to season, Gemmeiza 11 exhibit the highest value , whereas Giza 168and Sakha 93 revealed the least change.

Keywords: Wheat, Blumeria graminis f. sp. tritici, disease severity, AUDPC, crop
\end{abstract} losses.

\section{INTRODUCTION}

Wheat is an important cereal crop in Egypt and all over the world. It is a staple food crop and also known as "king" of the cereals (Laghari et al., 2010). Powdery mildew caused by Blumeria graminis (DC.) E.O. Speer f. sp. tritici Em. Marchal (Bgt), is one of the most devastating diseases of wheat worldwide especially under cool climates (Bennett, 1984). Disease severity depends on many factors including cultural practices, weather conditions and the degree of cultivar susceptibility (Fried et al., 1979). Powdery mildew infection reduces supply of photosynthesis and nitrogen re-translocation from leaves thus affecting yield components (Fried et al., 1979; Bowen et al., 1991).

Generally, the yield losses depend on the stage of plant growth when infection accurse (Griffey et al., 1993).Development of resistant varieties is the most effective, economically and environmentally friendly approach for disease control (Alam et al., 2013). The most common breeding strategy has been the use of major genes conferring hypersensitive types of resistance, 
but the effectiveness of this approach has commonly been ephemeral due to frequent changes in the pathogen population .

The main objective of this study was to determine the effect of powdery mildew on wheat grain yield and flour quality in the tested in nine Egyptian wheat varieties.

\section{MATERIALS AND METHODS}

The experiment was carried out at Gemmeiza Agricultural Research Station during 2012/13 and 2013/14 growing seasons under natural infection of powdery mildew. The experimental design was split plot design with three replicates. The main plots were devoted for fungicide treatment ( with\& without) while the split plots were devoted for tested varieties. The tested wheat varieties were Sakha 93, Giza 168, Gemmeiza 7, Gemmeiza 9, Gemmeiza 10, Gemmeiza 11, Misr 1, Misr 2 and Sids 12 (Table 1). The plot size was $6 \times 7 \mathrm{~m}=42 \mathrm{~m}^{2}$, each plot contained 20 rows with $6 \mathrm{~m}$ long and 30 $\mathrm{cm}$ between rows. Protected plots were treated three times with Sumi-eight 5 EC (1H-1,2,4-Triazole-1-ethanol,..beta.-[(2,4-dichlorophenyl)methylene].alpha.-(1,1-dimethylethyl)-,(.beta.E) (35 cc /100 L water) served as healthy control.

\section{Powdery mildew assessment:}

Powdery mildew severity was determined using the modified Cobb's scale 0 to $100 \%$ (Peterson et al., 1948), as the percentage of leaf surface area covered by mycelia. Disease severity assessment was recorded four times at 10-day intervals during the season; the first assessment made at the late booting stage (Growth Stage 45), and the last score was taken around G.S. 75, when the check cultivar reached its maximum severity. These values were used to calculate the area under disease progress curve (AUDPC) as described by Pandey et, al. (1989). The AUDPC was calculated for each variety as follows:

$$
\text { AUDPC }=D\left[1 / 2\left(Y_{1}+Y_{k}\right)+\left(Y_{2}+Y_{3}+\ldots .+Y_{k-1}\right)\right]
$$

Where: $D=$ Days between two consecutive recording (time intervals) $Y_{1}+Y_{k}=$ Sum of the first and last scores.

$Y_{2}+Y_{3}+\ldots-\ldots+Y_{k-1}=$ Sum of all in between disease scores.

\section{Determination of yield components:-}

When the plants reached the maturity stage, spikes of all plots were hand harvested, threshed and one thousand kernel weight ( $g$ ) and spike weight (g) were recorded. Randomly selected thousand grains from each genotype were weighed. Also, spike weight was determined for each variety. The percent reduction in each component was calculated according to the formula described by Colpauzos et al.,( 1976) as follow:

\section{Reduction (loss) \% = 1-Yd/Yh X 100}

Where: $Y d=$ yield of diseased plants

$\mathrm{Yh}=$ yield of healthy plants 


\section{Determination of flour quality:-}

Grain quality tests were done at laboratory of the National Gene Bank, ARC, Giza, Egypt as follow:

\section{Determination of total carbohydrate:-}

Total Carbohydrate was determined using the phenol sulphuric acid method according to Dubois et al (1956).

\section{Determination of total protein}

Protein percentage was determined using Kjeldahl apparatus as nitrogen percentage according to the Association of Official Agricultural Chemists(AOAC 1990) where, percentage of protein was obtained by multiplying nitrogen percentages by the factor 6.25 ( Sadasivam and Manickam,1996).

\section{Determination of wet gluten content:}

Wet gluten yield were determined according to AOAC,(1990) by machine washing method (GB/5506-85, National Standard of China). Paste was made with $25.00 \mathrm{~g}$ flour (w) mixed with $12.5 \mathrm{ml}$ of water, followed by washing for 10 minutes with water at a flow rate of $50-60 \mathrm{ml} / \mathrm{min}$ on a special 88-um sieve using a Perten Glutamatic Gluten Index machine (Perten Instruments AB, S-14105 Huddeings, Sweden). Afterwards, the wet gluten piece was centrifuged at $6000 \mathrm{rpm}$ for $1 \mathrm{~min}$ on a special 600 -um metallic sieve using a Perten Centrifuge 2015 machine (Perten Instruments AB, S14105 Huddeings, Sweden) and the wet gluten yield was obtained (WI). The wet gluten samples was cut into twelve pieces, placed in a tin and dried for 30 min at $155 \mathrm{C}$ using a special Perten Glutork 2020 dryer. After cooling in a desiccator, weight of dry gluten (W2) was recorded. The gluten index of wet gluten content (WGC) (Eq.1), dry gluten content (DGC) (Eq. 2) and moisture content of wet gluten (MCWG) (Eq.3) was obtained. Testes was carried out in triplicates for each sample.

$1-W G C=W 1 / W \times 100$

$2-D G C=W 2 / W \times 100$

3- MCWG = W1-W2/W2 $\times 100$

Statistical analysis:

Least significant differences (L.S.D. at $5 \%$ level of probability) were calculated to determine the significant differences between means ( Snedecor 1957). 
Table 1: List of the tested local wheat varieties, pedigree and year of release.

\begin{tabular}{|c|c|l|c|}
\hline No. & Variety & Pedigree & $\begin{array}{c}\text { Year of } \\
\text { release }\end{array}$ \\
\hline 1 & Sakha 93 & Sakha 92/TR 810328 S 8871-1S-2S-1S-0S & 1999 \\
\hline 2 & Giza 168 & MIL/BUC//Seri CM93046-8M-0Y-0M-2Y-0B & 1999 \\
\hline 3 & Gemmeiza 7 & $\begin{array}{l}\text { CMH74A.630/SX//SER182/3/AGENT. GM4611- } \\
\text { 2GM-3GM-1GM-0GM. }\end{array}$ & 1999 \\
\hline 4 & Gemmeiza 9 & $\begin{array}{l}\text { ALD"S"/HUAC"S"//CMH74A.630/SX. GM4583- } \\
\text { 5GM-1GM-0GM. }\end{array}$ & 1999 \\
\hline 5 & Gemmeiza 10 & $\begin{array}{l}\text { MAYA74"S"/0N//160- } \\
\text { 147/3/BB/GLL/4/CHAT"S"/5/CROW"S". GM5820- } \\
\text { 3GM-1GM-2GM-0GM. }\end{array}$ & 2004 \\
\hline 6 & Gemmeiza 11 & $\begin{array}{l}\text { BOW"S"/KVZ"S"//7C/SERI82/3/GIZA168/SAKHA6 } \\
\text { 1. GM7892-2GM-1GM-2GM-1GM-0GM. }\end{array}$ & 2011 \\
\hline 7 & Misr 1 & $\begin{array}{l}\text { OASIS/SKAUZ//4*BCN/3/2*PASTOR. } \\
\text { CMSSOYO1881T-050M-030Y-O3OM-030WGY- } \\
\text { 33M-0Y-0S. }\end{array}$ & 2011 \\
\hline 8 & Misr 2 & $\begin{array}{l}\text { SKAUZ/BAV92. CMSS96M0361S-1M-010SY- } \\
\text { 010M-010SY-8M-0Y-0S. }\end{array}$ & 2011 \\
\hline 9 & Sids 12 & $\begin{array}{l}\text { BUC//7C/ALD/5/MAYA74/ON//1160- } \\
\text { 147/3/BB/GLL/4/CHAT"S"/6/MAYA/VUL//CMH74 } \\
\text { A.630/4*SX.SD7096-4SD-1SD-1SD-0SD. }\end{array}$ & 2007 \\
\hline
\end{tabular}

\section{RESULTS}

\section{Evaluation of the tested wheat varieties for powdery mildew under field conditions:}

The tested wheat varieties showed different disease severities $\%$ in the two growing seasons (2012/13 and 2013/14).

Data in Table (2) in 2012/13 indicated that wheat varieties Giza 168, Sids 12 , Misr 1 , and Misr 2 showed low levels of powdery mildew severity $\%$ i.e. $4.33 \%, 4.33 \%, 4.33 \%$ and $8.33 \%$, respectively. Whereas, wheat cvs. Gemmiza 9 and Sakha 93 showed high levels of powdery mildew severity $41.66 \%$ and $38.33 \%$ respectivily. Area under disease progress curve (AUDPC) ran in parallel line with disease severity. The lowest values of AUDPC were recorded on the wheat varieties Giza 168 (40), Sids 12 (40), Misr 1 (40) followed by Misr 2 (181.5). While, wheat varieties Gemmiza 9 and Sakha 93 showed the highest values of AUDPC (840 and 825) during $2012 / 13$ growing season. The other wheat varieties were in between these two limits. 
Table 2: Powdery mildew severity (\%) and area under disease progress curve (AUDPC) of 9 wheat varieties under field conditions during 2012/13 and 2013/14 growing seasons at Gemmiza Agric. Res. Station.

\begin{tabular}{|l|c|c|c|c|}
\hline \multirow{2}{*}{ varieties } & \multicolumn{2}{|c|}{$\mathbf{2 0 1 2 / 1 3}$} & \multicolumn{2}{c|}{$\mathbf{2 0 1 3 / 1 4}$} \\
\cline { 2 - 5 } & $\begin{array}{c}\text { Disease } \\
\text { severity (\%) }\end{array}$ & AUDPC & $\begin{array}{c}\text { Disease } \\
\text { severity (\%) }\end{array}$ & AUDPC \\
\hline Sakha 93 & 38.33 & 825.0 & 51.66 & 915.00 \\
\hline Giza 168 & 4.33 & 40 & 8.33 & 185.5 \\
\hline Gemmeiza 7 & 18.33 & 240 & 31.66 & 565.0 \\
\hline Gemmeiza 9 & 41.66 & 840.0 & 41.66 & 840.0 \\
\hline Gemmeiza 10 & 28.33 & 560.0 & 38.33 & 825.0 \\
\hline Gemmeiza 11 & 21.66 & 240 & 21.66 & 240 \\
\hline Misr 1 & 4.33 & 40 & 8.33 & 181.5 \\
\hline Misr 2 & 8.33 & 181.5 & 21.66 & 240 \\
\hline Sids 12 & 4.33 & 40 & 8.33 & 185.5 \\
\hline L.S.D & 9.78 & 26.5 & 10.82 & 25.3 \\
\hline
\end{tabular}

AUDPC: area under disease progress curve

Data in Table (2) also revealed that the wheat varieties Giza 168, Misr 1 and Sids 12 each showed $8.33 \%$ powdery mildew severity with low values of AUDPC (185.5-181.5 and 185.5) respectively in 2013/2014 season. Whereas, wheat varieties Sakha 93, Gemmiza 9 and Gemmiza 10 showed high levels of powdery mildew severity i.e. $51.66 \%, 41.66 \%$ and $38.33 \%$, respectively. Whereas the other wheat varieties under study were in between. Regarding to the data shown in table 2 in 2013/2014 the highest values of AUDPC was recorded on the wheat variety Sakha 93 (915) whereas the least AUDPC value observed on Misr 1(181.5) .

\section{Yield reduction:}

Yield losses due to powdery mildew infection of the nine wheat varieties under study were estimated during 2012/13 and 2013/14 growing seasons. Data in Tables ( 3 and 4 ) revealed that the loss in yield components was correlated with disease severity during the two growing seasons.

Data in Tables (3 and 4) showed that the loss in 1000- kernel weight ranged from $1.13 \%$ in Sids 12 to $12.09 \%$ in Sakha 93 during 2012/13 growing season. Other varieties showed reduction between these two limits. In season 2013/2014 the loss in the 1000 kernel weight was higher than in the previous season on Sakha 93 showed $15.86 \%$ reduction, whereas Misr 2 showed the lowest value of loss $(1.2 \%)$

The loss in spike weight ranged from $2.2 \%$ in Sids 12 to $26.36 \%$ in Gemmeiza 10 during 2012/13 growing season. Other varieties showed loss in spike weight within these two extremes. Regarding the loss in spike weight in 2013/2014 Gemmeiza 7 and Gemmeiza 10 was the most affected variety by powdery mildew infection as they gave the highest values of loss $(22.25 \%$ 
and $22 \%$ ). On the other hand Sids 12 was the least affected variety followed by Giza 168 (8.03\% and $8.5 \%$ respectively) where they showed the least amounts of losspercentages.

Table 3: Effect of powdery mildew (Blumeria graminis) infection on 1000- kernel weight $(\mathrm{gm})$ of 9 wheat varieties at Gemmiza Agric. Res. station during 2012/13 and 2013/14 growing seasons.

\begin{tabular}{|l|c|c|c|c|c|c|}
\hline \multirow{2}{*}{ Variety } & \multicolumn{3}{|c|}{$\mathbf{2 0 1 2 / 1 3}$} & \multicolumn{3}{c|}{$\mathbf{2 0 1 3 / 1 4}$} \\
\cline { 2 - 7 } & \multicolumn{2}{|c|}{$\mathbf{1 0 0 0}$ kernel weight (gm) } & \multicolumn{2}{|c|}{$\mathbf{1 0 0 0}$ kernel weight (gm) } \\
\cline { 2 - 7 } & Infected & Protected & Loss (\%) & Infected & Protected & $\begin{array}{c}\text { Loss } \\
\text { (\%) }\end{array}$ \\
\hline Sakha 93 & 35.26 & 40.11 & 12.09 & 35.00 & 41.51 & 15.68 \\
\hline Giza 168 & 38.11 & 39.8 & 4.26 & 39.41 & 40.3 & 2.2 \\
\hline Gemmeiza 7 & 43.31 & 45.6 & 5.02 & 42.1 & 46.32 & 9.11 \\
\hline Gemmeiza 9 & 36 & 38.11 & 5.53 & 37.8 & 39.33 & 3.89 \\
\hline Gemmeiza 10 & 40 & 42.7 & 6.32 & 40.31 & 44.6 & 9.61 \\
\hline Gemmeiza 11 & 43.65 & 45.8 & 4.69 & 40.2 & 45.22 & 11.1 \\
\hline Misr 1 & 38.9 & 39.5 & 1.51 & 38.21 & 39.5 & 3.26 \\
\hline Misr 2 & 39 & 40.2 & 2.98 & 39.6 & 40.1 & 1.2 \\
\hline Sids 12 & 43.61 & 44.11 & 1.13 & 40.11 & 43.62 & 8.04 \\
\hline L.S.D. at 5 \% & 0.22 & 0.14 & & 1.23 & 0.064 & \\
\hline
\end{tabular}

\section{Grain quality assessment:}

\section{1-Protein content:}

Grain quality is a complex character that can be affected by many factor, one of the most important is diseases severity. The impact of powdery mildew on percentages of protein content varied with cultivar and disease severity (Tables 5 ).

Table 4: Effect of powdery mildew infection on spike weight of 9 wheat varieties at Gemmiza Agric. Res. station during 2012/13 and 2013/14 growing seasons.

\begin{tabular}{|c|c|c|c|c|c|c|}
\hline \multirow{2}{*}{ Variety } & \multicolumn{3}{|c|}{ 2012/13 } & \multicolumn{3}{c|}{ 2013/14 } \\
\cline { 2 - 7 } & \multicolumn{3}{|c|}{ spike weight (gm) } & \multicolumn{3}{c|}{ spike weight (gm) } \\
\cline { 2 - 7 } & Infected & Protected & Loss (\%) & Infected & Protected & Loss (\%) \\
\hline Sakha 93 & 2.33 & 3.00 & 22.33 & 2.59 & 3.21 & 19.31 \\
\hline Giza 168 & 3.14 & 3.51 & 10.5 & 2.88 & 3.15 & 8.5 \\
\hline Gemmeiza 7 & 3.00 & 3.82 & 21.46 & 3.11 & 4.00 & 22.25 \\
\hline Gemmeiza 9 & 2.41 & 3.11 & 22.5 & 2.61 & 3.25 & 19.69 \\
\hline Gemmeiza 10 & 2.00 & 2.91 & 26.36 & 2.41 & 3.09 & 22.00 \\
\hline Gemmeiza 11 & 3.01 & 3.42 & 11.98 & 3.11 & 3.65 & 14.79 \\
\hline Misr 1 & 2.81 & 2.93 & 4.09 & 2.6 & 3.2 & 18.75 \\
\hline Misr 2 & 2.93 & 3.11 & 5.78 & 2.9 & 3.4 & 14.7 \\
\hline Sids 12 & 3.11 & 3.18 & 2.20 & 3.32 & 3.61 & 8.03 \\
\hline L.S.D. at 5 \% & 0.25 & 0.083 & & 0.0745 & 0.105 & \\
\hline
\end{tabular}


The obtained data revealed that, highest values of increase $\%$ in protein content were observed with infected plants of Sakha 93 and Gemmeiza 9 (15.85 and 10.9) respectively in 2012/2013. On the other hand Giza 168 showed the least increase \% (1.15). The other cultivars exhibited different values of protein content and different increase percentages.

The same trend was experienced in 2013/2014. Sakha 93 was the most affected cultivar with powdery mildew infection which revealed high increase $\%$ in protein content $(14.14)$. These results correlated with powdery mildew severity.

Table 5: Effect of powdery mildew infection on protein content during 2012/13 and 2013/14 growing seasons.

\begin{tabular}{|l|c|c|c|c|c|c|}
\hline \multirow{2}{*}{ Variety } & \multicolumn{3}{|c|}{$\mathbf{2 0 1 2 / 2 0 1 3}$} & \multicolumn{3}{c|}{$\mathbf{2 0 1 3 / 2 0 1 4}$} \\
\cline { 2 - 7 } & Infected & Protected & Increase \% & Infected & Protected & Decrease\% \\
\hline Sakha 93 & 13.31 & 11.2 & 15.85 & 13.43 & 11.53 & 14.14 \\
\hline Giza 168 & 13.88 & 13.72 & 1.15 & 13.81 & 13.77 & 0.28 \\
\hline Gemmeiza 7 & 14.9 & 13.8 & 7.38 & 15.14 & 13.82 & 8.71 \\
\hline Gemmeiza 9 & 14.42 & 12.84 & 10.9 & 14.33 & 12.64 & 11.79 \\
\hline Gemmeiza 10 & 15.02 & 14.8 & 1.46 & 15.00 & 14.5 & 3.33 \\
\hline Gemmeiza 11 & 13.9 & 12.93 & 6.97 & 13.94 & 12.91 & 7.38 \\
\hline Misr 1 & 14.8 & 13.65 & 7.77 & 14.79 & 13.6 & 8.04 \\
\hline Misr 2 & 13.85 & 12.77 & 7.79 & 13.8 & 12.75 & 7.6 \\
\hline Sids 12 & 14.83 & 13.32 & 10.1 & 14.61 & 13.3 & 8.96 \\
\hline L.S.D. at 5 \% & 0.0986 & 0.0913 & & 0.064 & 0.0833 & \\
\hline
\end{tabular}

\section{Carbohydrate content:}

The impact of disease on carbohydrate content varied among cultivars and between the two seasons (Table 6). Results revealed that Gemmeiza 7 showed the highest decrease \% in carbohydrate content during 2012/13 season ( 6.64 ) followed by Misr 1 (4.72). Gemmeiza 9 exhibit the least decrease level (1.14\%).

Table 6: Effect of powdery mildew infection on carbohydrate content during 2012/13 and 2013/14 growing seasons.

\begin{tabular}{|l|c|c|c|c|c|c|}
\hline \multirow{2}{*}{ Variety } & \multicolumn{3}{|c|}{ 2012/2013 } & \multicolumn{3}{c|}{ 2013/2014 } \\
\cline { 2 - 7 } & Infected & Protected & Increase\% & Infected & Protected & Decrease\% \\
\hline Sakha 93 & 61.4 & 62.9 & 2.38 & 61.5 & 63 & 2.38 \\
\hline Giza 168 & 58 & 59.9 & 3.17 & 60.1 & 61.1 & 1.62 \\
\hline Gemmeiza 7 & 57.6 & 61.7 & 6.64 & 57.6 & 61.83 & 0.84 \\
\hline Gemmeiza 9 & 60.2 & 60.9 & 1.14 & 60.3 & 60.7 & 0.65 \\
\hline Gemmeiza 10 & 57.5 & 60.2 & 4.48 & 57.8 & 60.2 & 3.98 \\
\hline Gemmeiza 11 & 60 & 61.8 & 2.91 & 59.93 & 60.5 & 0.94 \\
\hline Misr 1 & 60.5 & 63.5 & 4.72 & 59.41 & 60.7 & 2.12 \\
\hline Misr 2 & 61 & 62.5 & 2.4 & 62.3 & 62.9 & 0.95 \\
\hline Sids 12 & 60 & 61.6 & 2.59 & 60.61 & 61.5 & 1.44 \\
\hline L.S.D. & 0.174 & 0.370 & & 0.129 & 0.139 & \\
\hline
\end{tabular}


In 2013/14 a little decrease \% in carbohydrate content i.e. ranged from 0.65 in Gemmeiza 9 to 3.98 in Gemmeiza 10. There was no significant effect of powdery mildew infection on carbohydrate content in some wheat cultivars, i.e. Gemmeiza 9 , Gemmeiza 7 and Gemmeiza 11.

Wet gluten content:

Results in table (7) showed that Giza 168 and Gemmeiza 7 exhibited the least increase (\%) in wet gluten $(3.2 \%$ and $3.5 \%)$, respectively. On the other hand Gemmeiza 11 followed by Gemmeiza 9 reveled the highest increase \% during the two successive seasons $(16.29 \%$ and $13.25 \%)$ and $(18.62 \%-11.3 \%)$ respectively. Sakha 93 showed the least increase( \%) in wet gluten in 2013/14 growing season which reveled $3.79 \%$.

Table 7: Effect of powdery mildew infection on Wet gluten content during 2012/13 and 2013/14 growing seasons.

\begin{tabular}{|l|c|c|c|c|c|c|}
\hline \multirow{2}{*}{ Variety } & \multicolumn{3}{|c|}{$\mathbf{2 0 1 2 / 2 0 1 3}$} & \multicolumn{3}{|c|}{$\mathbf{2 0 1 3 / 2 0 1 4}$} \\
\cline { 2 - 7 } & Infected & Protected & Increase \% & Infected & Protected & Decrease\% \\
\hline Sakha 93 & 31.11 & 30 & 3.56 & 31.6 & 30.4 & 3.79 \\
\hline Giza 168 & 31.2 & 30.2 & 3.2 & 30 & 28.6 & 4.66 \\
\hline Gemmeiza 7 & 34.2 & 33 & 3.5 & 29 & 26.43 & 8.86 \\
\hline Gemmeiza 9 & 33.2 & 28.8 & 13.25 & 33.6 & 29.8 & 11.3 \\
\hline Gemmeiza10 & 33.43 & 31.6 & 5.47 & 33.00 & 31.12 & 5.69 \\
\hline Gemmeiza11 & 35.6 & 29.8 & 16.29 & 34.63 & 28.18 & 18.62 \\
\hline Misr 1 & 29.6 & 27.31 & 7.73 & 29.8 & 28.3 & 5.11 \\
\hline Misr 2 & 32.9 & 30.6 & 6.07 & 31.92 & 29.6 & 7.26 \\
\hline Sids 12 & 34.6 & 31 & 10.4 & 30.16 & 28.94 & 4.04 \\
\hline L.S.D. at 5 \% & 0.182 & 0.705 & & 0.511 & 0.123 & \\
\hline
\end{tabular}

\section{DISCUSSION}

This study aimed to determine the effect of powdery mildew (Blumeria graminis f.sp. tritici) infection on spike grain yield and some bread-making quality using nine Egyptian wheat varieties conditions during the two successive seasons 2012/13 and 2013/14.

Powdery mildew severity\% was recorded for each of the tested wheat genotypes. The three wheat varieties Giza 168, Misr 1 and Sids 12 showed an adequate level of resistance to powdery mildew infection showing low levels of disease severity (4.33\% and $8.33 \%$ ) during season 2012/13and $2013 / 14$ respectively. On the other hand, Sakha 93 exhibited the highest disease severity $(38.33 \%$ and $51.66 \%)$ during the two successive seasons. The variation in disease severity among different varieties and growing seasons were also represented by others (Vechet, 2006 and El-Shamy et al. 2012).

According to the obtained results and depending on the values of AUDPC, it could be stated that the wheat varieties Giza 168, Misr 1 and Sids 12 showed high and appropriate levels of adult plant resistance to powdery mildew infection under field conditions during the two seasons. These 
varieties showed the lowest values of AUDPC less than 300 (El-Shamy et al., 2012).

Spike grain yield and yield components are complex characters and may be affected by the cumulative result of different physiologic processes, one of them powdery mildew infection. In this study, Sids 12, Misr 1 and Misr 2 showed the lowest losses in 1000-kerenl weight during the two seasons. The highest loss in 1000-kerenl weight was recorded on Sakha 93 which could be the reflective of powdery mildew susceptibility. Tomas and Solis (2000) concluded that the reduction in grain yield of the durum wheat cultivars in South of Spain was mainly caused by powdery mildew infection. El-Shamy et al. (2012) found that the highest reduction in yield components was detected in cv. Gemmeiza 10 i.e. the loss in kernel weight was (16.72\%) and in grain yield $/ \mathrm{m}^{2}$ was $(17.73 \%)$ in season 2009/10. In 2010/11 the loss in 1000 grain wheat ranged from $0.17 \%$ to $0.47 \%$, while grain yield $/ \mathrm{m}^{2}$ ranged from $0.27 \%$ to $1.28 \%$.

Regarding the grain quality, height disease pressure (Dereje, and Chemeda2007) reported that a reduction of starch biosynthesis of common bean (Phaseolus vulgaris L.) due to infection by common bacterial blight (caused by Xanthomonas axonopodis pv. phaseoli). He found that an interruption of normal starch synthesis due to disease may result in nitrogen increase at the loss of starch. When powdery mildew infection attacks wheat varieties at early stage it resulted in shriveled kernels and shriveling of kernels most often results in increased grain protein due to an increase in the ratio of protein to starch (Alam et al., 2013). Increase in disease pressure resulted in a significant increase in flour protein and loss of photosynthetic leaf area. Flour produced from grain grown under disease pressure would tend to have both higher protein content and higher water absorption (Everts et al., 2001).

\section{REFERENCES}

AOAC, 1990. Official Methods of Analysis of the Association of Official Analytical Chemists $15^{\text {th }}$ ed. Washington DC 20044 USA.

Alam, M.A., M.S.N. Mandal, C. Wang and W. Ji., 2013. Chromosomal location and SSR markers of a powdery mildew resistance gene in common wheat line N0308. African J. of Microbiology Research, $7(6): 477-482$.

Bennett, F.G.A., 1984. Resistance to powdery mildew in wheat: A review of its use in agriculture and breeding programmes. Plant Pathol., 33:279300.

Briceno-Felix, G., J. Huerta-Espino, L. Torres, J.A. Betbese and J.A. Martin Sanchez, 2004. Yield losses caused by powdery mildew on bread wheat cultivars under irrigated Mediterranean conditions in Spain. Options Mediterranean, Series A, No. 81:183-185. 
Bowen, K.L., K.L. Everts and S. Leath, 1991. Reduction in yield of winter wheat in North Carolina due to powdery mildew and leaf rust. Phytopatholog, 81: 503-511.

Colpauzos J., A.P. Roelfs, M.E. Madson, F.B. Martin, R.D. Wilconxson, 1976. A new model to measure yield losses caused by stem rust in spring wheat. Agric. Exp. Sta. Univ.Minnesota, Tech. Bull., 307:1-23.

Dereje, H. and F. Chemeda, 2007. Relationship between stripe rust (Puccinia striiformis) and grain quality of bread wheat (Triticum aestivum) in the highlands of Bale, southeastern Ethiopia. J. Food, Agric. \& Environment, Vol.5 (2): 24-30.

Dubois, M., K.A. Gilles, Hamilton J.K., Rebers, P.A. and F. Smith 1956. Colorimetric method for determination of sugars and related substances, Anal. Chem., 29. 350-356.

El-Shamy, M.M, Minas Sallam and H.M.F. Awad 2012. Powdery mildew infection on some Egyptian bread wheat cultivars in relation to environmental conditions. J. Plant Prot. and Path., Mansoura Univ., 3: 363-372.

Everts, K. L., S. Leath and P. L. Finney, 2001. Impact of powdery mildew and leaf rust on milling and baking quality of soft red winter wheat. Plant Dis. 85:423429.

Fried, P.M., D.R. MacKenzenzie and R.R. Nelson. 1979. Disease progress curves of Erysiphe graminis $f$. sp. tritici on Chancellor wheat and four multilines. Phytopathology Z., 95:151-166.

Griffey, C.A., M.K. Das and E.L. Stromberg. 1993. Effectiveness of adultplant resistance in reducing grain yield loss to powdery mildew in winter wheat. Plant Dis., 77:618-622.

Laghari, K.A., M.A. Sial, M.A. Arain, A.A. Mirbahar, A.J. Pirzada, M.U. Dahot and S.M. Mangrio. 2010. Heritability studies of yield and yield associated traits in bread wheat. Pak. J. Bot., 42(1):111-115.

Pandey H.N., T.C.M.Menon and M.V. Rao, 1989. A simple formula for calculating area under disease progress curve. Rachis 8:38-39.

Peterson, R.F., A.B. Campbell and A.E. Hannah, 1948. A diagrammatic scale for estimating rust intensity on leaves and stems of cereals. Can. J. Res., 26:496-500

Sadasivam, S and Manickam, A. 1996. Biochemical Methods. New Age International $(P)$ Limited, Second Edition, New Dewlhi 110002. India.

Snedecor, G.W. 1957. Statistical Methods, 5th eds.lowa State College Press, Ames, lowa.

Tomas, A. and I. Solis 2000. Effects of powdery mildew (Blumeria graminis) severity on durum wheat cultivars. Ciheam-Options Mediterraneeannes, Serie A. N. 40, 417-419.

Vechet, L. 2006. Reaction of winter wheat cultivars and breeding lines to Blumeria graminis f. sp. tritici. Plant Protection Science, 42: 15-20. 
تاثير الاصابه بالبياض الدقيقى على محصول الحبوب والجودة لبعض اصناف القمح

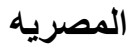

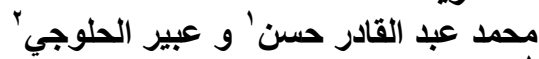

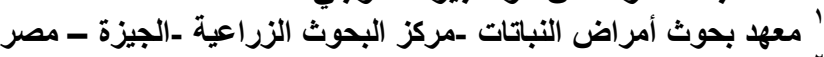

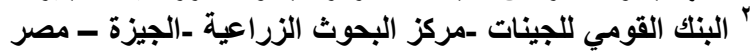

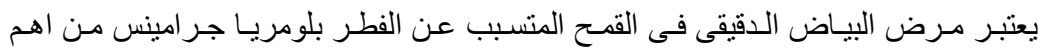

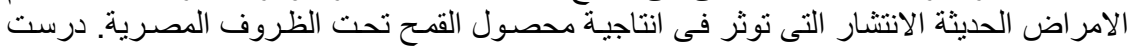

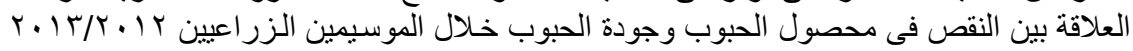

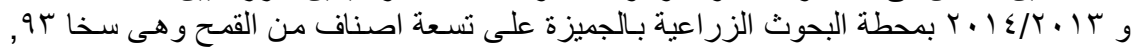

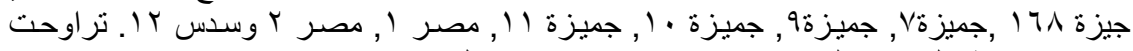

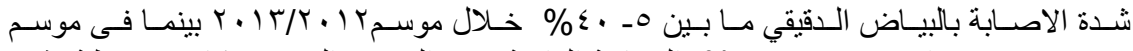

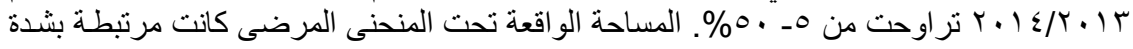

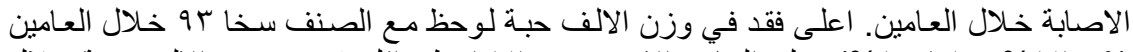

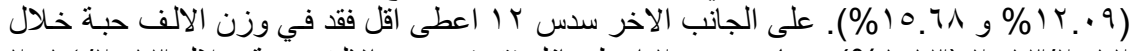

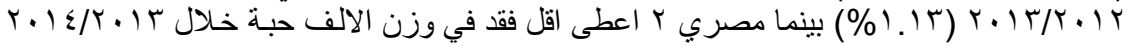

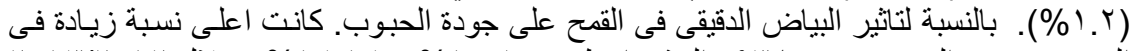

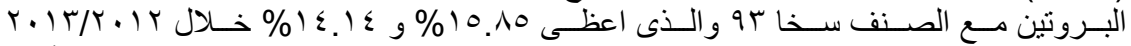

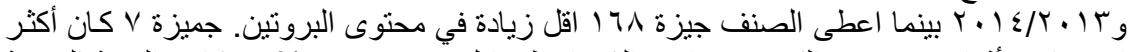

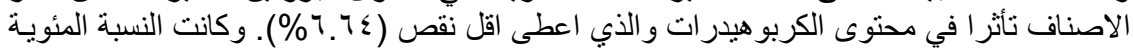

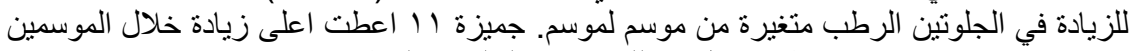

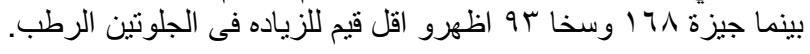

